\title{
Corrigendum to \\ "Inhibition of Key Digestive Enzymes \\ Related to Diabetes and Hyperlipidemia and \\ Protection of Liver-Kidney Functions \\ by Trigonelline in Diabetic Rats" \\ [Sci Pharm. 2013; 81: 233-246]
}

\author{
Khaled HAMDEN * ${ }^{1}$, Kais MNAFGUI ${ }^{2}$, Zahra AMrI ${ }^{2}$, \\ Ahmed Aloulou ${ }^{3}$, Abdelfattah ELFEKI ${ }^{2}$
}

${ }^{1}$ Biotechnology High School of Sfax (ISBS), University of Sfax, Soukra Km 45; PO Box 261, Sfax 3038, Tunisia.

${ }^{2}$ Laboratory of Animal Ecophysiology, University of Sfax, Faculty of Sciences of Sfax, PO Box 95, Sfax 3052, Tunisia.

${ }^{3}$ Laboratory of Biochemistry and Enzymatic Engineering of Lipases, National School of Engineers of Sfax, University of Sfax, Sfax 3038, Tunisia.

* Corresponding author. E-mails: khaledhamden@yahoo.fr or Khaled.Hamden@isbs.rnu.tn (K. Hamden)

Sci Pharm. 2014; 82: 449-450

doi:10.3797/scipharm.1211-14corr

Published: $\quad$ March $13^{\text {th }} 2014$

Accepted: $\quad$ March $13^{\text {th }} 2014$

Received: $\quad$ March $9^{\text {th }} 2014$

This article is available from: http://dx.doi.org/10.3797/scipharm.1211-14corr

(c) Hamden et al.; licensee Österreichische Apotheker-Verlagsgesellschaft m. b. H., Vienna, Austria.

This is an Open Access article distributed under the terms of the Creative Commons Attribution License (http://creativecommons.org/licenses/by/3.0/), which permits unrestricted use, distribution, and reproduction in any medium, provided the original work is properly cited.

\begin{abstract}
This is a corrigendum to the article 'Inhibition of Key Digestive Enzymes Related to Diabetes and Hyperlipidemia and Protection of Liver-Kidney Functions by Trigonelline in Diabetic Rats' [Sci Pharm. 2013; 81: 233-246]. Figure 6 is replaced.
\end{abstract}

\section{Keywords}

Corrigendum • Sci Pharm. 2013; 81: 233-246

Unfortunately, Figure 6 incorrectly appeared in the published article due to a numbering problem of the blades used for the pictures [1]. Hence, this wrong figure should be replaced with the correct one given below. The authors are very sorry for this error and for any inconvenience this caused. 


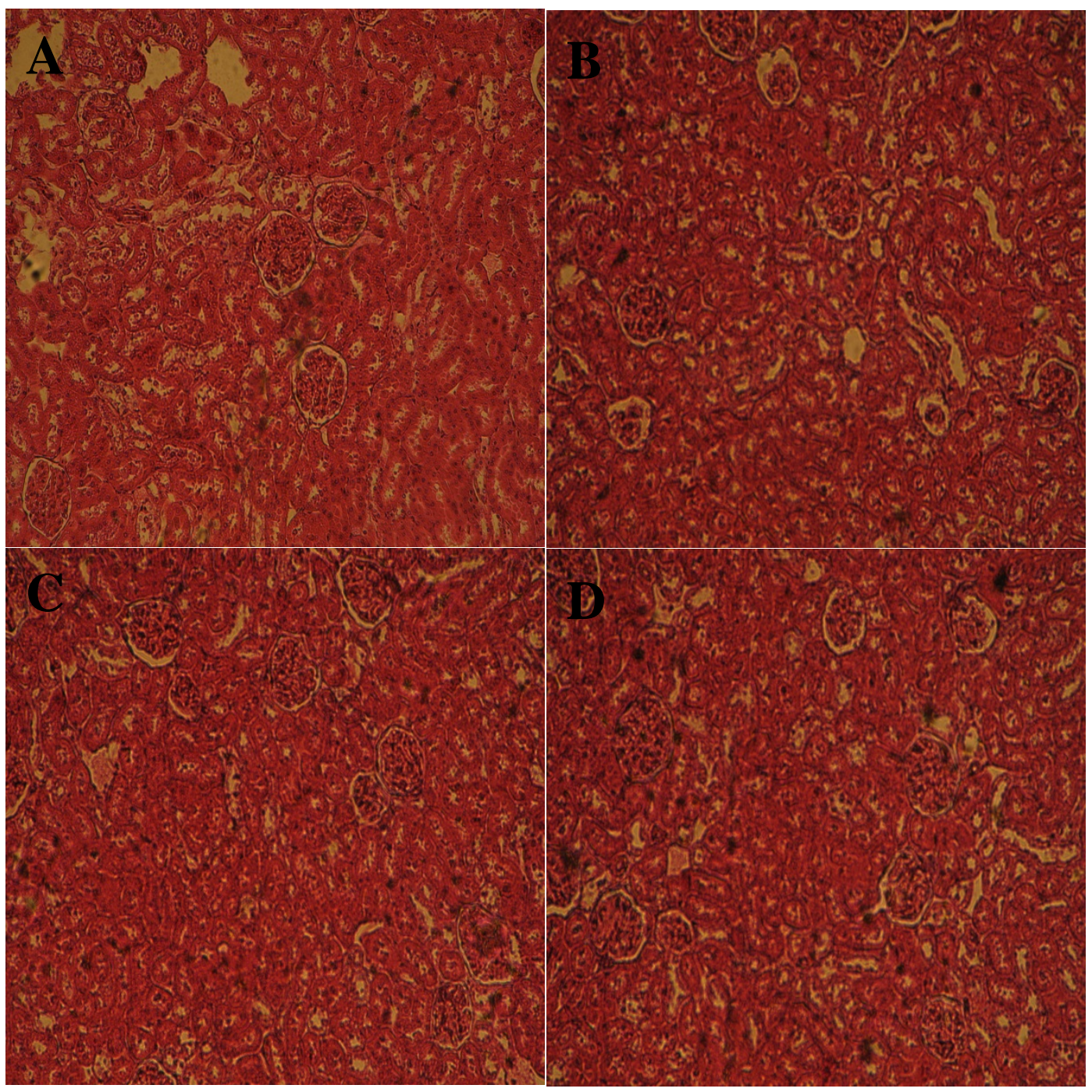

Fig. 6. Histopathological studies of the kidney in the control and experimental groups of rats. Section of the kidney from A) control rats; B) diabetic rats at day 30 showing histopathological changes (e.g. capsular space shrinkage and glomerular hypertrophy); C, D): diabetic rats treated respectively with Acar and trigonelline, the protective action was shown.

\section{Authors' Statement}

\section{Competing Interests}

The authors declare no conflict of interest.

\section{Reference}

[1] Hamden K, Mnafgui K, Amri Z, Aloulou A, Elfeki A.

Inhibition of key digestive enzymes related to diabetes and hyperlipidemia and protection of liverkidney functions by trigonelline in diabetic rats.

Sci Pharm. 2013; 81: 233-246.

http://dx.doi.org/10.3797/scipharm.1211-14 